\title{
The tissue-specific and developmental expression patterns of the forkhead transcription factor FoxO1 gene in pigs*
}

\author{
Y. Liu, Y. Wang ${ }^{1}$, T. Shan, J. Guo, Ch. Xu and J. Liu \\ Institute of Feed Science, Zhejiang University, \\ The Key Laboratory of Molecular Animal Nutrition, Ministry of Education \\ No.164 Qiutao North Road, Hangzhou, 310029, P.R. China
}

(Received 5 December 2006; revised version 10 March 2008; accepted 8 April 2008)

\begin{abstract}
The forkhead transcription factor FoxO1 has been studied as the most downstream targets of the signaling pathway in mammals, and played a key role in adipogeneic, cell cycle progression, and energy metabolism and so on. The aim of this study was to investigate the tissue-specific and weight-dependent expression patterns of FoxO1 gene in porcine omental adipose tissue and its relation to adipose deposition. Sixty female Duroc $\times$ Landrace $\times$ Yorkshire pigs in 5 groups, each group containing twelve pigs weighing $1,20,40,60$, and $90 \mathrm{~kg}$ were used to study developmental expression of FoxO1 gene by means of semi-quantitative RT-PCR. The results showed that FoxO1 mRNA was expressed at a higher level in heart, brain, omental adipose tissue, skeletal muscle, liver and spleen, at a moderate level in kidney, lung, and peritoneal adipose tissue, and at a less level in duodenum, subcutaneous adipose tissue and pancreas. In addition, our data also showed that the expression levels of FoxO1 gene was lowest in the pigs at $20 \mathrm{~kg}$, and continuously increased from 20 to $90 \mathrm{~kg}$ body weight $(\mathrm{P}<0.05)$. Furthermore, a close positive correlation between the expression levels of FoxO1 gene and the adipose deposition rate was found in pigs $(\mathrm{r}=0.84, \mathrm{P}<0.05)$.
\end{abstract}

KEY WORDS: pig, FoxO1, gene expression, adipose tissue, fat deposition

\section{INTRODUCTION}

The forkhead transcriptional factor subfamily forkhead box O1 (FoxO1) is a member of the FoxO subfamilies of forkhead transcription factors, which is

\footnotetext{
* Supported by the Fund of National Basic Research Program (973), No. 2004 CB117506

${ }^{1}$ Corresponding author: e-mail: chuxn@zju.edu.cn
} 
deemed to the most downstream targets of the signaling pathway in mammals, such as insulin-like growth factor (IGF)/phosphoinositide 3-kinase (PI3K)/Akt signaling pathway. Insulin-mediated activation of Akt phosphorylates FoxO1, leads to its nuclear exclusion, results in reduced transcriptional activity, and inhibits the expression of FoxO1-regulated genes (Burgering and Kops, 2002), which affect apoptosis (Brunet et al., 1999; Dijkers et al., 2000; Nakae et al., 2003), energy metabolism (Puigserver et al., 2003; Frescas et al., 2005), tumorigenesis (Seoane et al., 2004; Greer and Brunet, 2005), cell cycle progression (Alvarez et al., 2001; Zhang et al., 2005), cellular differentiation, growth, and proliferation (Accili and Arden, 2004; Machida and Booth, 2004).

FoxO1 was involved in the differentiation of adipose tissues and obesity by a high-fat diet in mouse (Nakae et al., 2003). At the stage of adipogenesis, FoxO1 was activated and cooperated with PPAR $\gamma$ and C/EBP $\beta$ to regulating the switch from clonal expansion to differentiation. A recent study of the mouse using siRNA technology showed that hypothalamic FoxO1 affected feed intake and body weight through regulating feed intake and energy homeostasis (Kim et al., 2006). In addition, FoxO1 up-regulated lipoprotein lipase expression in skeletal muscle, while lipoprotein lipase was ascertained a key enzyme of lipidic metabolism (Kamei et al., 2003). These several evidences showed that FoxO1 was involved in fat deposition progression.

However, there are no data about tissue-specific and developmental expression patterns of FoxO1 gene in pigs. Moreover, the total fat depots keeping at optimum level are key factor to efficiently produce good quality porcine meat. So the aim of this study was to determine the pattern of FoxO1 gene expression in different tissues, different growth stages and its relation to adipose deposition to obtain information for regulating meat production quality.

\section{MATERIAL AND METHODS}

\section{Animals}

All of the experiments were done according to the guidelines for animal experiments at the National Institute of Animal Health. Total of sixty female pigs (Duroc $\times$ Landrace $\times$ Yorkshire) weighed at 1, 20, 40, 60 and $90 \mathrm{~kg}(\mathrm{n}=$ 12 /group) were grouped by body weight and were fed ad libitum according to the National Research Council guidelines. Thirty female pigs $(\mathrm{n}=6 /$ group) were selected randomly, weighted and euthanized under anaesthesia after a $12 \mathrm{~h}$ fast and ad libitum access to water. Omental adipose tissue (OA) of all pigs, and subcutaneous adipose tissue (SA), peritoneal adipose tissue (PA), brain (BR), heart (HE), liver (LI), kidney (KI), lung (LU), spleen (SP), skeletal muscle (SM), 
duodenum (DU) and pancreas (PC) of pigs at $20 \mathrm{~kg}$ were quickly dissected and frozen in liquid nitrogen, then stored at $-70^{\circ} \mathrm{C}$ until extraction of total RNA. Lefthalf carcasses were weighed after the head, tail, hooves, viscera (except the KI) were removed. OA, PA and SA in left-half carcasses were dissected and weighed, and fat deposition rates were calculated according to the previous study (Shan et al., 2006).

\section{Extraction of RNA and synthesis of $c D N A$}

Total RNA from each tissue sample was isolated using RNeasy Mini Kit (Qiagen, Maryland, USA) according to the manufacture's instructions. The extracted RNA was dissolved in ultra pure water and the purity and concentration of total RNA were measured by a spectrophotometer at 260 and $280 \mathrm{~nm}$. And then, the first cDNA was synthesized according to the method of previous studies (Wang et al., 2005; Shan et al., 2006).

\section{$R T-P C R$}

Primer sequences for FoxO1 gene were designed based on porcine sequences available in GenBank. 18S rRNA was more reliable than other genes (beta-actin gene, etc.) as an internal control gene for the gene expression research (Mauro and Edelman, 1997; Selvey et al., 2001). So, samples were normalized using the housekeeping gene, $18 \mathrm{~S}$ rRNA. Two pairs of primers were designed by the Primer Premier 5.0 software (Table 1), and synthesized by Shanghai Sangon Biological

Table 1. Primers sequences for FoxO1 and 18S rRNA genes

\begin{tabular}{|c|c|c|c|c|}
\hline Gene & $\begin{array}{c}\text { Accession } \\
\text { number }\end{array}$ & $\begin{array}{l}\text { Primer } \\
\text { source }\end{array}$ & Oligonucleotide sequence & $\begin{array}{c}\text { Length } \\
\text { bp }\end{array}$ \\
\hline FoxO1 & $\begin{array}{l}\text { DQ243692 } \\
\text { (5 204 bp) }\end{array}$ & Pig & $\begin{array}{l}\text { '-AAGACCGCTTTACAAGTGCC-3' } \\
\text { sense primer } \\
\text { 5'-TCTCCATCCATGAGGTCGTT-3' } \\
\text { antisense primer }\end{array}$ & 200 \\
\hline $\begin{array}{ccc}1 & 8 & \mathrm{~S} \\
\text { rRNA } & \end{array}$ & $\begin{array}{l}\text { AY265350 } \\
(631 \sim 1005 \mathrm{bp})\end{array}$ & Pig & $\begin{array}{l}\text { 5' - CTCCACCAACTAAGAACGG- 3' } \\
\text { (sense primer) } \\
\text { 5' - AAGACGGACCAGAGCGAAA-3' } \\
\text { antisense primer }\end{array}$ & 375 \\
\hline
\end{tabular}

Engineering Technology and Services Co., Ltd. (China). The reverse- ranscribed cDNA was amplified with Taq DNA polymerase by polymerase chain reaction (PCR) in a thermocycler (Gene Amp PCR system 9600) using designed primers. 
RT-PCR for tested genes was performed in a $50-\mu 1$ final reaction volume. The appropriate number of cycles, optimum PCR primer concentration, Mg2+ concentration and annealing temperature that would result in linear amplification of each transcript were determined by a preliminary experiment (data not shown). The amplification reaction was constitutive of $1 \mu \mathrm{l}$ reverse-transcribed cDNA; $5 \mu 110 \times$ PCR buffer; $3 \mu 125 \mathrm{mM} \mathrm{MgCl} ; 1 \mu 120 \mu \mathrm{M}$ of each primer; $1 \mu 110$ $\mathrm{mM}$ dNTP; $0.5 \mu 1$ Taq DNA polymerase. The conditions for PCR for FoxO1 gene were: denaturation for 2 min at $94^{\circ} \mathrm{C}, 29$ cycles of PCR were performed with each cycle consisting of denaturation at $94^{\circ} \mathrm{C}$ for $50 \mathrm{~s}$, annealing at $52.5^{\circ} \mathrm{C}$ for $50 \mathrm{~s}$, and extension at $72^{\circ} \mathrm{C} 60 \mathrm{~s}$, and followed by final extension at $72^{\circ} \mathrm{C}$ for $10 \mathrm{~min}$. The conditions for PCR for 18S rRNA gene were: denaturation for 2 min at $94^{\circ} \mathrm{C}, 27$ cycles of PCR were performed with each cycle consisting of denaturation at $94^{\circ} \mathrm{C}$ for $50 \mathrm{~s}$, annealing at $53^{\circ} \mathrm{C}$ for $50 \mathrm{~s}$, and extension at $72^{\circ} \mathrm{C} 60 \mathrm{~s}$, and followed by final extension at $72^{\circ} \mathrm{C}$ for $10 \mathrm{~min}$.

\section{$D N A$ sequencing and $m R N A$ expression analysis}

DNA sequencing and sequence analysis were performed by the method described by Khoo et al. (2003). The expression of porcine FoxO1 gene was determined by semi-quantitative RT-PCR using the housekeeping 18S rRNA gene as control. Amplified products were electrophoresed through $1.0 \%(\mathrm{w} / \mathrm{v})$ agarose gel, electrophoresis band intensities of the PCR products were quantified using NIH Image Version 1.62 software.

\section{Statistical analysis}

The data were analysed according to the ANOVA procedure and the treatment means were separated by Duncan's multiple range tests (Duncan, 1955; SAS, 1989). P-values $<0.05$ were considered to be significant.

\section{RESULTS AND DISCUSSION}

The tissue-specific expression pattern of FoxO1 gene in tested tissues in pigs was evaluated using semi-quantitative RT-PCR. The results of electrophoresis of PCR products were shown in Figure 1. This study demonstrated the expression of FoxO1 gene in distant areas of porcine OA, SA, PA, BR, HE, LI, KI, LU, SP, $\mathrm{SM}, \mathrm{DU}$, and PC. Moreover, FoxO1 mRNA was expressed at a higher level in HE (SEM=0.0962), OA, SM, BR, LI and SP, and at a moderate level in KI, LU, PA, but, little was detected in DU, SA and PC. 
A

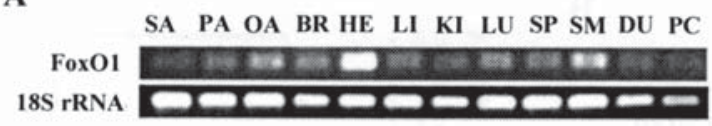

B

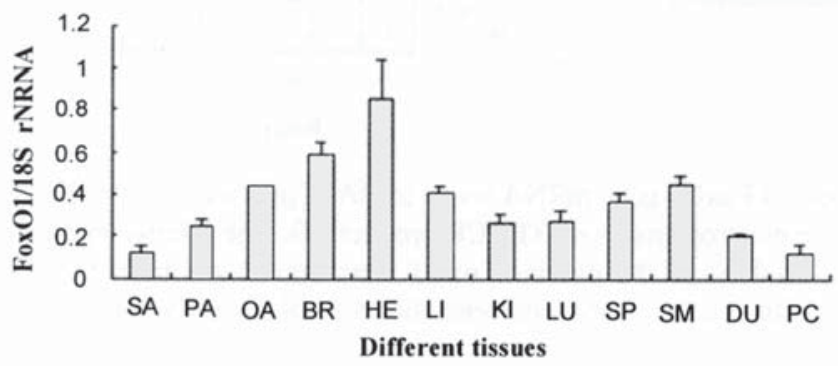

Figure 1. The tissue-specific expression pattern of FoxO1 gene mRNA in pigs weighted $20 \mathrm{~kg}$. A: Results of the electrophoresis of RT-PCR products in all tested tissues. B: The relative expression of FoxO1 in various porcine tissues. Densitometric analysis of the porcine FoxO1 were normalized to $18 \mathrm{~S}$ rRNA and shown as FoxO1/18S rRNA ratios. Each column represents the mean of six individual pigs \pm SEM

The tissue-specific expression pattern of FoxO1 gene was not reported in previous study, but it has been showed that FoxO1 was widely expressed in the different tissues in human and mouse. Anderson et al. (1998) detected the expression of FoxO1 gene in adult human tissues using the RT-PCR analysis and Northern blot analysis, and FoxO1 gene was expressed in heart, brain, lung, liver, skeletal muscle, kidney, pancreas, spleen, thymus, prostate, testis, ovary, placenta, small intestine and peripheral blood leukocytes. Furuyama et al. (2000) examined the FoxO1, FoxO3, and FoxO4 genes tissue distribution in mouse by Northern-blot analysis and found that the expressions of FoxO1, FoxO3, and FoxO4 were highest in brown adipose tissue, white adipose tissue in muscle, SP, HE and BR. The data of Nakae et al. (2002) indicated that FoxO1 was the most abundant FoxO isoform in murine white and brown adipose tissue. These results were basically similar with our data, and scanty differentiations may be due to the diversity of species.

The developmental expression pattern of FoxO1 gene in porcine OA with liveweight of 1,20,40,60, and $90 \mathrm{~kg}$ was evaluated, and the results of electrophoresis of PCR products were shown in Figure 2. Our data showed that the expression levels of FoxO1 gene change with growing. In details, the expression of FoxO1 gene was at a low concentration at birth. However, the expression of FoxO1 gene was lowest in pigs with liveweight of $20 \mathrm{~kg}$, and then steadily increased as the pigs grew. Furthermore, the expression of FoxO1 gene was observed significantly increase in pigs of $90 \mathrm{~kg}$ weight when compared with pigs at $20 \mathrm{~kg}(\mathrm{P}<0.05)$. The highest expression of FoxO1 gene was observed at the highest body weight, $90 \mathrm{~kg}$. 


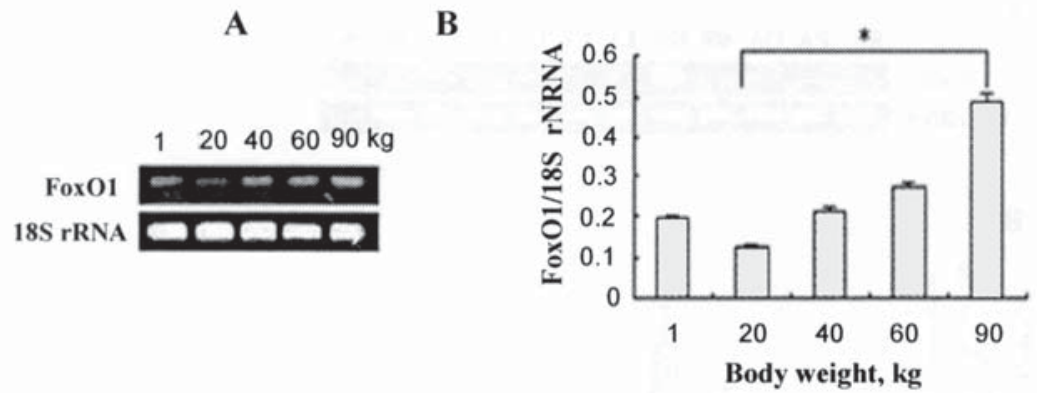

Figure 2. The pattern of FoxO1 gene mRNA levels in OA of pigs weighted 1, 20, 40, 60, and 90 $\mathrm{kg}$. A: The results of the electrophoresis of RT-PCR products. B: The relative expression of FoxO1 in OA. Densitometric analysis of the porcine FoxO1 were normalized to $18 \mathrm{~S}$ rRNA and shown as FoxO1/18S rRNA ratios. Each column represents the mean of six individual pigs $\pm \mathrm{SEM}$. ${ }^{*} \mathrm{P}<0.05$

At the presentstudy, there was no description about the developmental expression pattern of FoxO1 gene in porcine OA. It has been reported the expression of FoxO1 gene emerged a temporally restricted manner in the adult and developing mouse brain (Hoekman et al., 2006). Whereas, Furuyama et al. (2002) described no significant change with aging in rat skeletal muscles, and reported that the gene expression of FoxO1 was remarkably and selectively induced in mouse skeletal muscle and white adipose tissue with starvation (Furuyama et al., 2003).

In addition, the data of Nakae et al. (2003) showed that FoxO1 regulated adipocyte differentiation in vitro. In 3T3-F442A preadipocytes, original mRNA levels of FoxO1 were comparably low, increased up to 6-fold over basal levels at day 4 , and then partially declined during differentiation.

To validate the correlation between the expression level of FoxO1 gene and the fat deposition, the fat (SA, PA and OA) deposition rates were calculated (data no show). It was known that FoxO1 gene mRNA level increased simultaneously as fat deposited from 1 to $90 \mathrm{~kg}$ body weight (Figure 3). Correlation analysis

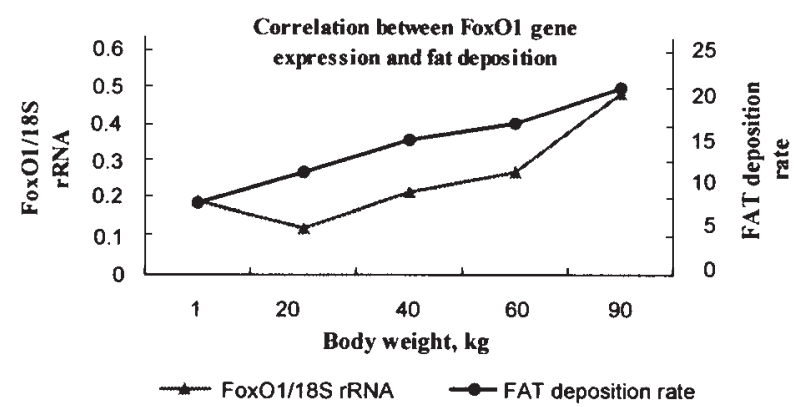

Figure 3. The correlation between FoxO1 gene expression in $\mathrm{OA}$ and fat deposition rate in pigs weighted 1, 20, 40, 60, and $90 \mathrm{~kg}$ 
demonstrated that there was a significantly positive correlation between the expression levels of FoxO1 gene and the fat deposition rate during growth from 1 to $90 \mathrm{~kg}$ body weight $(\mathrm{r}=0.84, \mathrm{P}<0.05)$.

This result indicated that the fat deposition rates significantly increased with growing in pigs $(\mathrm{P}<0.01)$. This was agreed with the data of Wang et al. (1989) who reported that the fat percentage increased significantly when the weight of commercial lean pigs increased and Souza et al. (2004) who described a significant correlation between fat content of the carcass and animal age.

Several experimental approaches have revealed that FoxO1 played a key role in the adipogenic and body weight. The study by Kim et al. (2006) showed that hypothalamic FoxO1 played an important role in the up-regulation of body weight and feed intake. FoxO1 regulated gluconeogenesis and adipocyte differentiation by regulating the expression of the target genes such as CCAAT/enhancing-binding protein (C/EBP), p27, glucose-6-phosphatase (G-6-Pase), phosphoenolpyruvate carboxykinase (PEPCK), and peroxisome proliferator-activated receptor gamma $\left(\right.$ PPAR $\left._{\gamma}\right)$. Futhermore, the present study showed that the expression of these target genes increased as fat was deposited in adipose tissue (Tontonoz et al., 1994; Jiang et al., 2006). These results demonstrated the positive relation between the expression of FoxO1 gene and body weight. In our results, the positive correlation between expression levels of FoxO1 gene and fat deposition rate may be due to modulation of FoxO1 in lipid metabolism in adipose tissue, and may be due to FoxO1 participation in the adipocyte differentiation.

\section{CONCLUSIONS}

Our study revealed that the expression pattern of FoxO1 gene had a tissuespecific and weight-dependent change, and demonstrated the positive relation with fat deposition in pigs. The results of this study would provide some information needed for the use of development of nutritional schemes and gene therapy to manipulate porcine fat deposition in regulating and improving meat production quality. Further study on the molecular mechanism of FoxO1 action is also important to stockbreeding and a clinical viewpoint.

\section{REFERENCES}

Accili D., Arden K.C., 2004. FoxOs at the crossroads of cellular metabolism, differentiation, and transformation. Cell 117, 421-426

Alvarez B., Martinez A.C., Burgering B.M., Carrera A.C., 2001. Forkhead transcription factors contribute to execution of the mitotic programme in mammals. Nature 413, 744-747

Anderson M.J., Viars C.S., Czekay S., Cavenee W.K., Arden K.C., 1998. Cloning and characterization of three human forkhead genes that comprisean FKHR-like gene subfamily. Genomics 47, 187-199 
Brunet A., Bonni A., Zigmond M.J., Lin M.Z., Juo P., Hu L.S., Anderson M.J., Arden K.C., Blenis J., Greenberg M.E., 1999. Akt promotes cell survival by Phosphorylating and inhibiting a Forkhead transcription factor. Cell 96, 857-868

Burgering B.M., Kops G.J., 2002. Cell cycle and death control: long live Forkheads. Trends Biochem. Sci. 27, 352-360

Dijkers P.F., Medema R.H., Lammers J.M., Koenderman L., Coffer P.J., 2000. Expression of the proapoptotic Bcl-2 family member Bim is regulated by the Forkhead transcription factor FKHR-L1. Curr. Biol. 10, 1201-1204

Duncan D.B., 1955. Multiple range and multiple F test. Biometrics 11, 1-42

Frescas D., Valenti L., Accili D., 2005. Nuclear trapping of the forkhead transcription factor FoxO1 via Sirt-dependent deacetylation promotes expression of glucogenetic genes. J. Biol. Chem. 280, 20589-20595

Furuyama T., Kitayama K., Yamashita H., Mori N., 2003. Forkhead transcription factor FOXO1 (FKHR)-dependent induction of PDK4 gene expression in skeletal muscle during energy deprivation. Biochem. J. 375, 365-371

Furuyama T., Nakazawa T., Nakano I., Mori N., 2000. Identification of the differential distribution patterns of mRNAs and consensus binding sequences for mouse DAF-16 homologues. Biochem. J. 349, 629-634

Furuyama T., Yamashita H., Kitayama K., Higami Y., Shimokawa I., Mori N., 2002. Effects of aging and caloric restriction on the gene expression of FoxO1, 3, and 4 (FKHR, FKHRL1, and AFX) in the rat skeletal muscles. Microsc. Res. Technique 59, 331-334

Greer E.L., Brunet A., 2005. FOXO transcription factors at the interface between longevity and tumor suppression. Oncogene 50, 7410-7425

Hoekman M.F.M., Jacobs F.M.J., Smidt M.P., Burbach J.P.H., 2006. Spatial and temporal expression of FoxO transcription factors in the developing and adult murine brain. Gene Expression Patterns $6,134-140$

Jiang J.F., Xu Z.R., Wang Y.Z., Han X.Y., Wang L., 2006. Postnatal expression pattern of the C/EBP alpha gene in porcine subcutaneous adipose tissue. J. Anim. Feed Sci. 15, 61-70

Kamei Y., Mizukami J., Miura S., Suzuki M., Takahashi N., Kawada T., Taniguchi T., Ezaki O., 2003. A forkhead transcription factor FKHR up-regulates lipoprotein lipase expression in skeletal muscle. FEBS Lett. 536, 232-236

Khoo B.Y., Samian M.R., Najimudin N., Tengku Muhammad T.S., 2003. Molecular cloning and characterization of peroxisome proliferator activated receptor gamma 1 ( PPAR $_{\gamma}$ )cDNA gene from guinea pig (Cavia porcellus): determination of tissue distribution of $\operatorname{PPAR}_{\gamma}^{\gamma}$ in guinea pig. Comp. Biochem. Physiol. Pt B 134, 37-44

Kim M.S., Pak Y.K., Jang P.G., Namkoong C., Choi Y.S., 2006. Role of hypothalamic FoxO1 in the regulation of food intake and energy homeostasis. Nat. Neurosci. 9, 901-906

Machida S., Booth F.W., 2004. Increased nuclear proteins in muscle satellite cells in aged animals as compared to young growing animals. Exp. Gerontol. 39, 1521-1525

Mauro V.P., Edelman G.M., 1997. rRNA-like sequences occur in diverse primary transcripts: Implications for the control of gene expression. Proc. Nat. Acad. Sci. USA 94, 422-427

Nakae J., Biggs W.H., Kitamura T., Cavenee W., Arden K.C., Accili D., 2002. Regulation of insulin action and pancreatic beta-cell function by mutated alleles of the gene encoding forkhead transcription factor FoxO1. Nat. Genet. 32, 245-253

Nakae J., Kitamura T., Biggs III W.H., Arden K.C., Accili D., 2003. The forkhead transcription factor FoxO1 regulates adipocyte differentiation. Develop. Cell 4, 119-129

Puigserver P., Rhee J., Donovan J., 2003. Insulin-regualted hepatic gluconeogenesis through FoxO1PGC-1 $\alpha$ interaction. Nature 423, 550-555 
SAS, 1989. SAS User's Guide, Version 6.4th Edition. SAS Institute Inc. Cary, NC

Seoane J., Le H.V., Shen L., 2004. Integration of smad and forkhead pathways in the control of neuroepithelial and glioblastoma cell proliferation. Cell 117, 211-223

Selvey S., Thompson E.W., Matthaei K., Lea R.A., Irving M.G., Griffiths L.R., 2001. ß-Actin - an unsuitable internal control for RT-PCR. Mol. Cell. Probe. 15, 307-311

Shan T.Z., Wang Y.Z., Liu Y.J., Liu J.X., Feng J., Xu Z.R., 2006. Developmental expression of the lipoprotein lipase gene in porcine subcutaneous adipose tissue. J. Anim. Feed Sci. 15, 621-629

Souza D.N., Pethick D.W., Dunshea D., Pluske J.R., Mullan B.P., 2004. The pattern of fat and lean muscle tissue deposition differs in the different pork primal cuts of female pigs during the finisher growth phase. Livest. Prod. Sci. 91, 1-8

Tontonoz P., Hu E., Spiegelman B.M., 1994. Stimulation of adipogenesis in fibroblasts by PPAR gamma 2, a lipid-activated transcription factor. Cell 79, 1147-1156

Wang B.L., Shao J.L., Zheng J.N., 1989. The research report on the growth and development rule in commercial lean pigs. Ning xia Agr. Ind. Technol. 10, 34-38

Wang Y.Z., Tu Y.J., Han F.F., Xu Z.R., Wang J.H., 2005. Developmental gene expression of lactoferrin and effect of dietary iron on gene regulation of lactoferrin in mouse mammary gland. J. Dairy Sci. 88, 1-7

Zhang H.S., Cao E.H., Qin J.F., 2005. Homocysteine induces cell cycle G1 arrest in endothelial cells through the PI3K/Akt/FOXO signaling pathway. Pharmacology 74, 57-64 